\title{
ANALYSIS OF THE GAINS IN THE WORKSTATIONS OF AN AUTOMOTIVE INDUSTRY FROM AN ERGONOMICS-BASED TIME AND MOTION STUDY
}

\author{
Maria Angélica Machado Dâmaso \\ Federal University of Lavras (UFLA), Automation Department, Campus, ZIP Code 37.200-900, Lavras, MG, Brazil.
}

\section{Cecília Toledo Hernández}

Federal Fluminense University (UFF), Production Engineering Department, Campus, 24.220-900, Rio de Janeiro, RJ, Brazil.

\section{Ricardo Rodrigues Magalhães}

Federal University of Lavras (UFLA), Automation Department, Campus, ZIP Code 37.200-900, Lavras, MG, Brazil. Corresponding author: ricardorm@ufla.br

\begin{abstract}
This work aims to apply techniques for the study of times, movements and ergonomics in workstations in an automobile industry in order to evaluate the productivity gains obtained with the change of work methods. In this way, a case study is presented in two jobs in that industry where changes in methods are necessary. To evaluate the new methods, working postures were studied using the ergonomic analysis methodology OWAS (Ovako Working Posture Analysis System) and the time of tasks was measured through Chrono analysis. As a result, there were simplifications in workstations, reduction of time and effort made by operators in carrying out their tasks, and, consequently, increased productivity. Finally, it is highlighted that the joint application of these tools allowed to eliminate waste and increase productivity without losing sight of comfort and safety for workers.
\end{abstract}

Index terms: Time study; OWAS method; production gain.

Received: May, 12, 2021 - Accepted: November 3, 2021

\section{INTRODUCTION}

Applying rational methods, managing activities and standardising processes towards increasing productivity is crucial for organisations, considering company factors such as increased environmental interrelation capacity and adaptation. Organisations are focused on optimising their processes, ensuring increased stability and adaptation to their market (Sousa et al., 2017).

A lot of challenges are imposed by the world economy, including high competitiveness standards through high technology, benefitcost ratios, and consumer demand for quality products whist considering environmental issues. In this context, processes must be more efficient, guaranteeing short delivery times and increasing productivity, often with a small number of workers. This streamlining results in work intensification and may generate, in ergonomics terms, unfavourable working conditions (Pinto, Tereso and Abrahão, 2018).
Most concepts of quality of life at work balance benefits for the employee and the company because improving the quality of life increases job satisfaction, sense of well-being, security, and pride whilst enhancing productivity, thereby leading to satisfactory financial results (Zanardi et al., 2015). In this context, time and motion study is a tool used to streamline work and it is also necessary to identify the occurrence of workrelated ergonomics risk factors in workstations (Sanjog, Patel and Karmakar, 2019).

Ergonomics must also be used to increase comfort for workers, who perform specific tasks in large industrial companies. Findings can facilitate informed decisions with respect to both engineering (e.g.ergonomic workstation and tool design) and administration (e.g. work organization) control strategies (NourollahiDarabad et al., 2020).

Some companies use an isolated and restricted way the concepts of time and motion study and ergonomics. At this point, it has to 
be highlighted that when these tools are used together, they provide great advantages for organizations (Lucas, Saes and Turati, 2017). Based on that, this work has as main objective to jointly apply the techniques of study of times, movements and ergonomics in two workstations of an industry of the automobile sector in order to rationalize the work, obtaining efficiency gains and ensuring comfort and safety of the workers.

\section{THEORETICAL FRAMEWORK}

\section{Time and motion studies}

Conduct working projects based on engineering concepts presents more comprehensive methods. It identifies possible improvements, requires using problem-solving techniques, focusing on method improvement, on production process analysis and standardization and on time and motion studies (Lucas, Saes and Turati, 2017).

The development phase of the new method consists of determining the best method within the existing restrictions on the study case, usually in combination with tests to assess performance improvement. Conversely, in the implementation phase, an action plan must be drawn up to present objectives and expected results. However, supervisors and operators should communicate with each other, primarily sharing information about the use of the new method. This preparation is essential because those responsible for this implementation are highly resistant to change. Last, the analysis of the results is highly important, and the study of the organisation should reach a conclusion regarding whether the goals set were achieved.

To evaluate the best working method, it is necessary to analyze the activities in all their aspects (Martins and Laugeni, 2005). The analyst must not be influenced by the current method, that is, before introducing improvements in the method under study, it is necessary to reconsider the problem to achieve its objective and lead the process to the implementation of the new method, which will allow its standardization and the possibility of establish standard times (Barnes, 2001). Time and motion studies highlight useless movements so that they can be excluded, which yields a lower average time, thereby increasing productivity efficiently and with quality and saving workers time and effort. The data from time and motion studies present the real time spent by the operator performing a series of consecutive steps, requiring the analysis of the operator speed to determine a pattern for an operator working at a normal pace with which the task can be performed within the time set (Barnes, 2001).

Standard times should be measured to serve as a future reference for the company's activities. The study starts by timing times (TC) of the activity that was previously divided into elements, establishing a reference speed (V) of the operator under study, this speed is subjectively established by the timekeeper or analyst and finally a factor is established tolerance (FT) that allows interruptions to rest for certain needs to be met. This TF can be found in tables according to the needs of the work or it can be determined by observations of the activity. The standard time can be calculated using Equations 1, 2 and 3 (Martins and Laugeni, 2005).

$\mathrm{NT}=\mathrm{OT} . \mathrm{V}$

$$
T F=\frac{1}{(1-p)}
$$

$$
\mathrm{ST}=\mathrm{NT} . \mathrm{TF}
$$

where: $N T=$ normal time (unit of time/product or operation)

OT = observed time (unit of time/product or operation)

$V=$ work pace $(100 \%$ reference value, can increase or decrease according to operator speed)

$p=$ ratio between total break time and total shift work time

$T F=$ tolerance factor (percentage values added to $100 \%$ as a function of rest needs as a function of the type of activity)

$S T=$ standard time (unit of time/product or operation) 


\section{ERGONOMICS}

Ergonomics (or human factors) is a scientific discipline focused on understanding interactions between humans and other elements or systems and applying theories, principles, data, and methods to projects to optimise human wellbeing and the global performance of a system. Ergonomists help to plan, design, and evaluate tasks, workstations, products, environments, and systems to make them compatible with people's needs, skills, and limitations (ABERGO, 2018).

The application of ergonomic principles is highly important for understanding the relationship between people and a work environment and aims to enhance worker safety, comfort, and well-being (Sousa and Filho, 2017). Assembly workers using handheld powered tightening tools are repetitively subjected to reaction loads resulting from the tool handle (Mazaheri and Rose, 2021).

Regulatory Standard NR17 establishes parameters that allow the adaptation of working conditions to the psychophysiological characteristics of workers, in order to provide maximum comfort, safety and efficient performance. In this sense, it is up to the employer to analyze ergonomic risk factors, those related to working posture being of great importance, given the effects they cause to the musculoskeletal system (NR 17, 1978).

To assess working postures, there are several ergonomic tools: OWAS Method - Ovako Working Posture Analysis System; RULA Method - Rapid Upper-Limb Assessment; REBA Method - Rapid Entire Body Assessment, among others.
There is no assessment tool that encompasses all the items associated with occupational risks, each of the tools has specific applications and are used according to the characteristics of the task (Castilho, Barbirato and Sales, 2015). The RULA is a method that aims to quickly assess potential damage to limbs, depending on the posture adopted (Trzaskos and Michaloski, 2015). The REBA method analyzes activities that develop unexpected changes in posture as a result of handling loads (Almeida, 2007). The OWAS method was proposed with the aim of identifying and evaluating inappropriate postures during the execution of a task and still considers the effort made (Trzaskos and Michaloski, 2015). Although Guimarães and Naveiro (2004) consider the OWAS method as very general, it is widely used because it adapts to the analysis of almost all occupational tasks.

OWAS is widely used in some fields of application (Brandl et al., 2017) and emerged from the need to identify and analyse inadequate postures in the performance of a task. Such inadequate postures may determine the onset of physical problems in operators, generating incapacity for work, absenteeism, and additional costs to the production process (Junior, 2006). The code of the OWAS tool for an adaptation to the software Ergolândia (ERGOLÂNDIA, 2018) is presented in Table 1.

After the postures are evaluated, the method calculates and classifies the respective workload in each activity, determining the measure to adopt (Table 2). In addition, the method identifies inadequate working conditions and indicates the most strained areas.

Table 1: OWAS tool code.

\begin{tabular}{cccc}
\hline & $2^{\text {nd }}$ Value & $3^{\text {rd Value }}$ & $4^{\text {th }}$ Value \\
\hline Back & Arms & Legs & Effort \\
\hline 1- Straight & 1- Both arms below the shoulder line & 1 - Sitting & 1 -Lower than $10 \mathrm{~kg}$ \\
2 - Bent & 2 - One arm above the shoulder & 2 - Stretching both legs & 2 - From 10 to $20 \mathrm{~kg}$ \\
3 - Twisted & 3- Both arms above the shoulders & 3 - Stretching one leg & 3 -Higher than $20 \mathrm{~kg}$ \\
4 -Twisted and bent & & 4 - Bending both legs & \\
& & 5 - Bending one leg & 6- Kneeling \\
\hline
\end{tabular}

Source: Adapted from the software Ergolândia (2018). 
Table 2: OWAS method action categories.

\begin{tabular}{lc}
\hline & Action categories \\
\hline 1 & No corrective measures are needed \\
2 & Corrective measures are needed in the near future \\
3 & Corrective measures are needed as soon as possible \\
\hline 4 & Corrective measures are needed immediately \\
\hline
\end{tabular}

Source: Adapted from the Software Ergolândia (2018).

\section{MATERIAL AND METHODS}

This study is an exploratory research with an applied nature, aiming to generate practical application knowledge to solve specific problems. The stages of the project are represented in order in Figure 1.

Data were collected through items such as ergonomics, time and motion studies, productivity, and workflow. Real-time analysis and surveys of company employees directly linked to the process were performed to identify possible problems within the organisation.

The observation of the movements performed by the workers during the tasks allowed the identification of problems and the elaboration of new proposals for working methods. These new working methods were evaluated from the perspective of the times and movements performed.

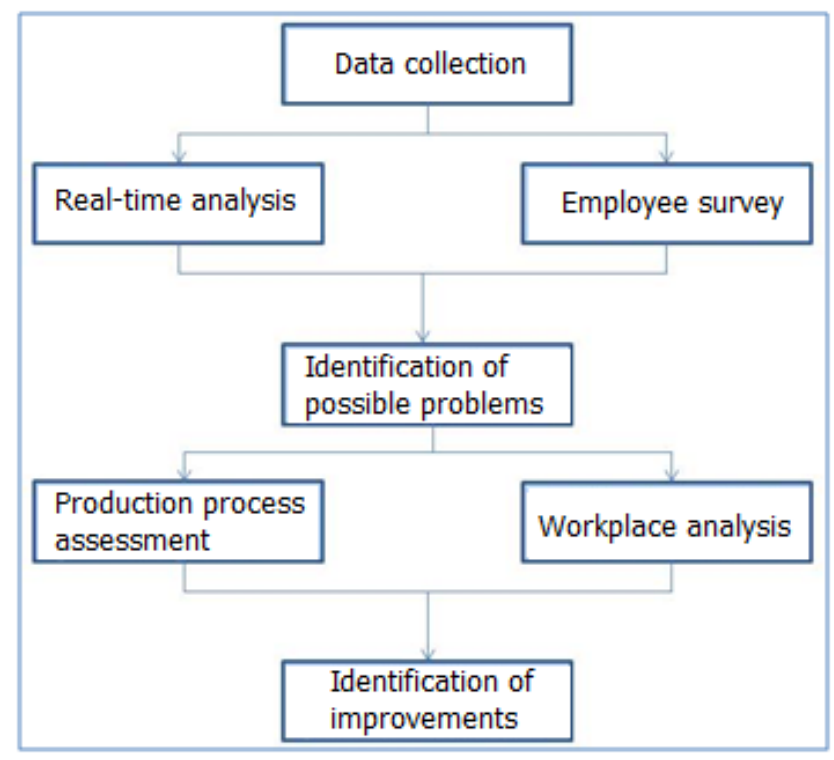

Figure 1: Project stages.

Source: From authors (2018).
To assess the movements, the postures assumed by the workers were verified, and data were entered into the Ergolândia software for the application of the OWAS assessment method. To study the times of each activity, the Chrono analysis technique was used. Based on this information, the production process and the working environment were assessed to propose improvements in line with the issues found in the study.

\section{CHARACTERISATION OF THE COMPANY}

The company under study is an automobile industry and consists of four production units: a body shop, a paint shop, interior assembly and an engine factory. The workstations studied are located in the factory assembly line because they are considered workstations with a high degree of complaints of daily discomfort. The research involved a survey of recurring situations in the daily lives of workers. For the workstations, the survey primarily focused on two operations of a given vehicle model, namely, tailgate wire harness routing (which is performed at the first workstation studied) and tailgate clamp assembly (which is performed in the second workstation studied).

At the first workstation, the first operation (tailgate wire harness routing) is performed through the tailgate. Conditions which the part was assembled, as well as the area through which the part is routed, were deemed unfavourable because the clamps are attached to the wire harness; as a result, the clamps become stuck in the hole when the harnesses routed through the lid. This operation is illustrated by the Figure 2 .

At the second workstation, tailgate clamp assembly, in which the operator inserts a total of 6 wire harness clips into the tailgate, is performed. In this case, the tailgate is open when the operation is performed to complete the assembly. This operation is illustrated by the Figure 3 .

The presence of clamps attached to the wire harness hinders its assembly in the tailgate of the vehicle, accounting for the long assembly time of the operation. In addition, this operation can cause discomfort in the operator who performs the task. 


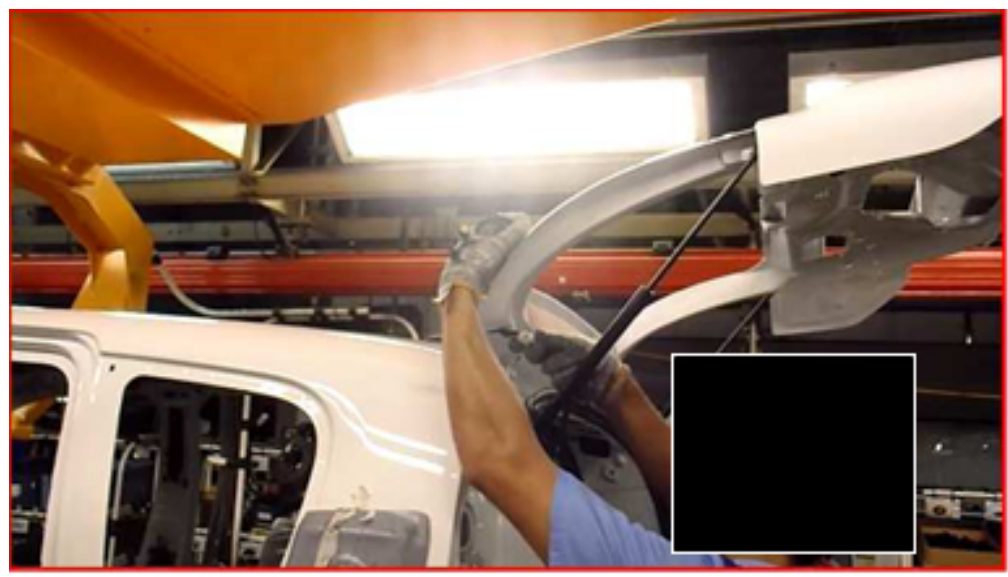

Figure 2: Tailgate wire harness routing. Source: From authors (2018).

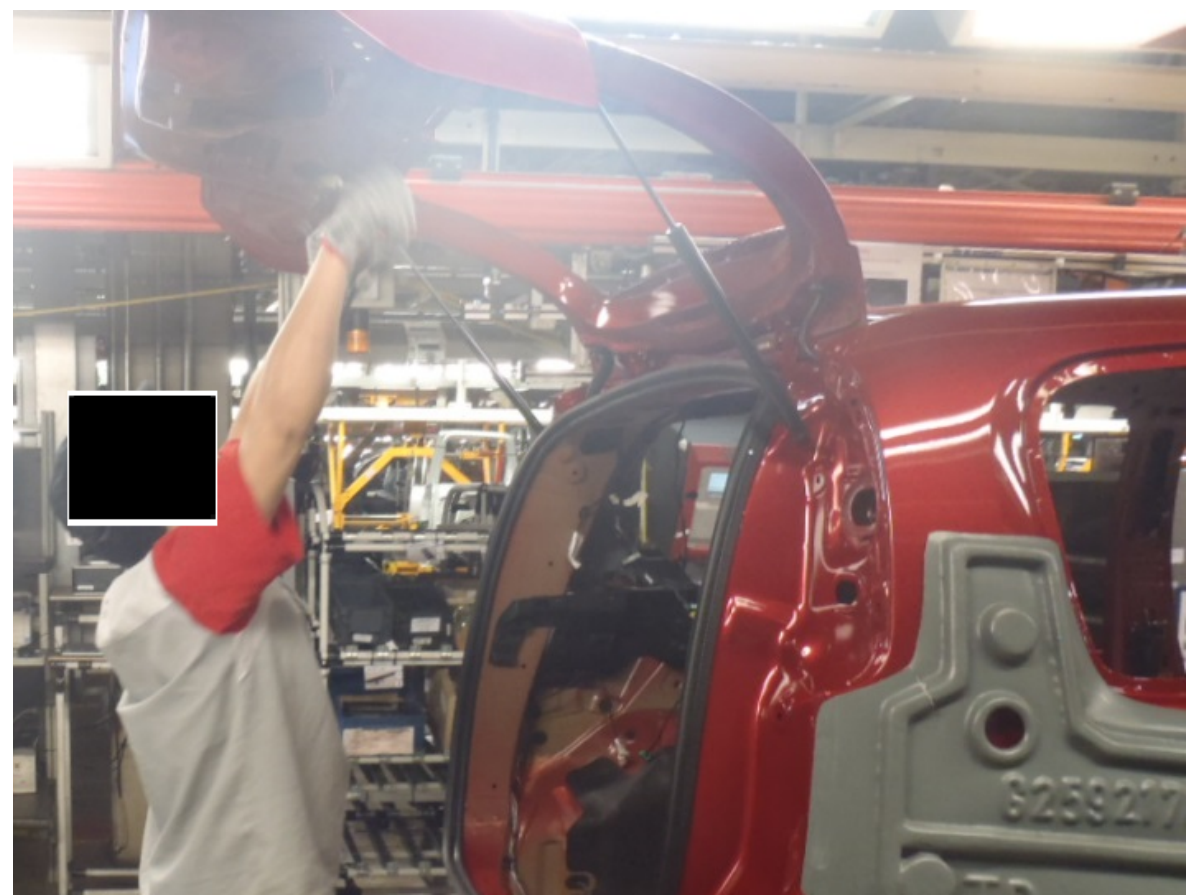

Figure 3: Tailgate wire harness assembly.

Source: From authors (2018).

\section{ROOT CAUSE IDENTIFICATION}

The potential causes of the problems can be identified by applying quality tools towards finding opportunities for improvement. Problems were observed in the productivity of the studied operations. Current situation of the workstations through an Ishikawa diagram is presented in Figure 4.

The Ishikawa diagram (Figure 4) shows the following:

- Manual labour: The employees who work in the studied workstations are demotivated because the operations are lengthy and non- ergonomic and the operating method used is exhausting, causing health problems and great discomfort and generating complaints at the healthcare centre of the company.

- Method: The way in which the operations are performed accounts for the long assembly time, thus reducing workstation productivity. Another key factor is the height difference between the vehicle and the operator, causing great discomfort in executing the tasks.

- Raw Material: The wire harness has integrated clamps that hinder the routing in the tailgate. In addition to this inconvenience, the 
hole in the tailgate has a small diameter, thus leading to non-ergonomic conditions.

- Measurement: As a consequence of other factors, the operating time is long, and sometimes assembly line stoppages occur, decreasing the productivity of the studied workstations.

Among the causes listed above, the method, raw material, and measurement are deemed the most important.

\section{DESCRIPTION OF THE WORK METHOD USED IN THE OPERATIONS}

\section{Current situation}

First, the activities executed by the operators responsible for the operations of tailgate wire harness routing and tailgate clamp assembly in the study workstations were identified. For this purpose, the mode of operation was assessed, and this information was complemented with observations at the workplace to evaluate the activities in question. Operations of the current situation are outlined by Table 3 .
All operations are conducted with the assembly line in progress; hence, any operational discrepancy can impact the entire assembly line by affecting the cadence of the vehicles moving in sequence.

One operator is required for operation 1 and another operator is required for operation 2 because the operations are performed at different workstations. In the event of a problem during the operation, the operator should activate a device, stopping the assembly line and therefore causing loss of productivity, thereby failing to produce a specific number of vehicles. According to data collected from production managers, in six months, the following events were detected:

- 6 complaints at the healthcare centre of the company;

- 279 assembly line stoppages;

- 754 Andon activations;

- 54:20 min stoppage time;

- Failure to produce approximately vehicles.

Following their analysis, the operations were separated into detailed activities. Of the ergonomics tools, OWAS is the most adequate tool because it uses the techniques that most closely match the situation under study.

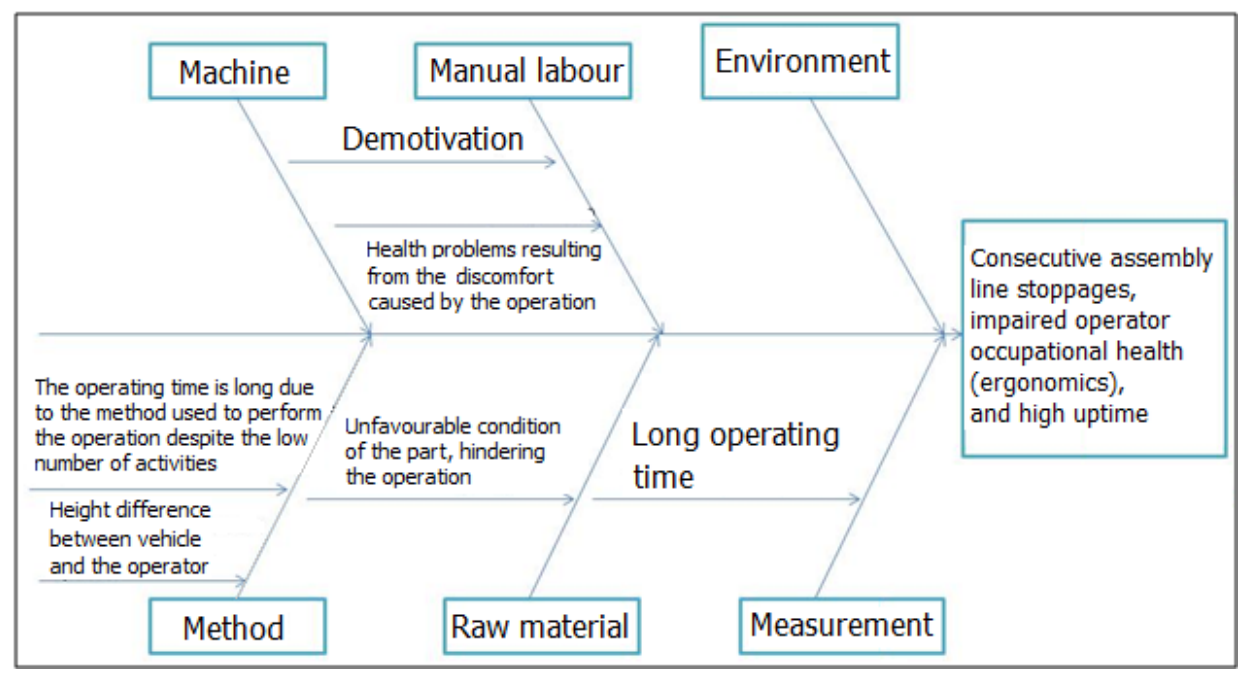

Figure 4: Ishikawa diagram for current problems.

Source: From authors (2018).

Table 3: Company current operations.

\begin{tabular}{|c|c|c|}
\hline & Operation & Description \\
\hline Operation 1 & Tailgate wire harness routing & Routing the tailgate wire harness through the hole in the tailgate \\
\hline Operation 2 & Tailgate clamp clipping & Clipping 6 clamps to the tailgate wire harness \\
\hline
\end{tabular}


This method evaluates the postures of different body segments (back, arms and legs), the strength and frequency at which each posture takes place, all of these aspects are essential in the operations under analysis. Details of the activities studied in the workstations are presented in Tables 4 and 5 .

The software Ergolândia was used to apply the OWAS tool based on records of the postures adopted by the operators when executing the study operations. As outlined in Tables 4 and 5 , the operations were analysed in depth. First, the activities of operation 1 and subsequently operation 2 were analysed, identifying the most critical activities requiring immediate corrections.

Activity 1 required immediate corrections within the action category, but the percentage of time was lower than those of other activities. Activity 2 of operation 1 required no corrective measures. The third activity of operation 1 required future corrections, but the percentage of time needed to execute this activity was considered to be longer than those of other activities of the study operation. Therefore, this activity also required corrections.

In addition, the posture of the operators, when their back was not straight, when one of their arms was at or above the shoulder line, and when they were standing with both legs stretched, needed corrections.

\section{Proposed situation}

After the mode of operation was determined, existing problems with the studied operations were assessed, and all observations and analyses were performed, a new work method was developed. For this purpose, daily analyses were performed on the assembly line for one month. During this period, the analyses showed that when executing operation 1 , the operator struggled considerably with routing the wire harness through the hole in the tailgate. For this reason, the clamps attached to the wire harness were removed, applying the six clamps mounted in the line-side (line-side assembly). Thus, the components were applied separately (wire harness and clamps). The proposed situation included another operation, albeit with decreased physical strain on the operator because the mode of operation was simpler and easier to perform.

The operations of tailgate wire harness routing and tailgate clamp assembly, which were performed at different workstations, started to be executed at the same workstation, with the addition of a new operation to the second study workstation (the operation of routing the wire harness through the clamps). The operations proposed for this situation are outlined in Table 6.

Despite executing a higher number of operations, the operator can perform them without difficulties because, by removing the attached clamps, the wire harnesses more easily routed through the tailgate hole, and this operation is deemed more critical. The new operation of tailgate wire harness routing is presented in Figure 5.

In the operations of clamp assembly (lineside assembly) and clamp routing through the tailgate, the operator manages to perform the operations without difficulties. The new operating method provides remarkable comfort. Moreover, the number of operators required to execute the operations remains unchanged.

Table 4: Activities list of operation1.

\begin{tabular}{cccccc}
\hline \multicolumn{2}{c}{ Operation: tailgate wire harness routing } & & & \\
\hline Time (\%) & Activity & Back & Arms & Legs & Effort \\
\hline 0.5 & 1 - Picking up the wire harness from the floor & 4 & 1 & 4 & 1 \\
27.5 & 2 - Unsealing the wire harness & 1 & 1 & 2 & 1 \\
72 & 3 - Routing the wire harness & 2 & 2 & 2 & 1 \\
\hline
\end{tabular}

Table 5: Activities list of operation 2.

\begin{tabular}{cccccc}
\hline \multicolumn{7}{c}{ Clipping the attached clamps in the tailgate } \\
\hline Time (\%) & Activity & Back & Arms & Legs & Effort \\
100 & 1 - Threading and clipping the wire harness & 1 & 3 & 2 & 1 \\
\hline
\end{tabular}


Table 6: Operations proposed for wire harness routing through the clamps.

\begin{tabular}{|c|c|c|}
\hline & Operation & Description \\
\hline OP 1 & Tailgate wire harness routing & $\begin{array}{l}\text { Routing the tailgate wire harness } \\
\text { through the hole in the tailgate }\end{array}$ \\
\hline OP 2 & $\begin{array}{l}\text { Clipping the clamps (line-side } \\
\text { assembly) in the tailgate }\end{array}$ & Clipping the 6 clamps (line-side assembly) in the tailgate \\
\hline OP 3 & Wire harness routing through the clamps & $\begin{array}{l}\text { Routing the wire harness through the } \\
\text { tailgate clamps }\end{array}$ \\
\hline
\end{tabular}

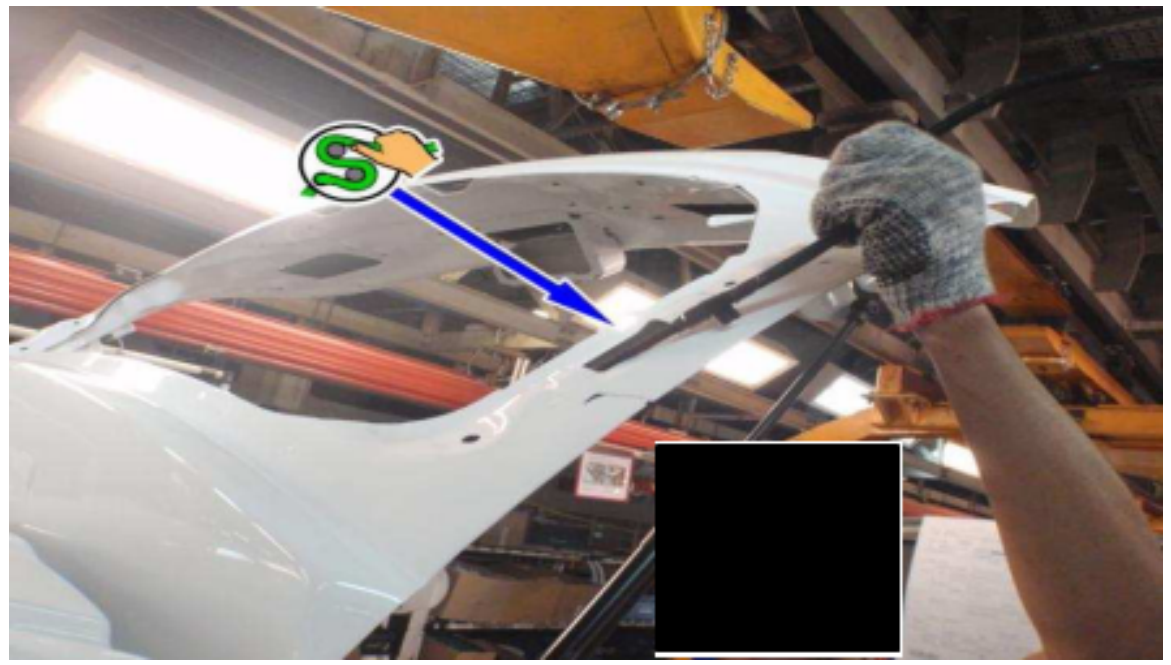

Figure 5: Tailgate wire harness routing through the tailgate hole.

Source: From authors (2018).

New work methods involve evaluating the way tasks are performed based on the movements performed (assessment of postures) and measuring the new times to determine the existence or not of gains with the consequent increase in productivity.

\section{RESULTS AND DISCUSSION}

\section{Results using the software Ergolândia}

The analysis of the activities presented in section Materials and Method showed the need for improving the wire harness routing because this operation took a long time to execute. The activities proposed for the workstations using the software Ergolândia, applying the OWAS tool are outlined by the Tables 7 to 9 .

The decreasing in the wire harness routing time is presented in Table 7 , considering the activities needed to execute operation 1 . Corrections were introduced to avoid back bending (Table 8), by removing the clamps from the wire harness, the posture with which the operator executes the operation improves significantly. Furthermore, while the clamps are assembled separately, the operator manages to do so without difficulties. Last, in operation 3 (Table 9), no movements were observed that compromise the operator's health. After these analyses (Tables 7-9), the software Ergolândia was applied to the new activities to assess the relationship between the postures proposed for the operators.

For the activity of picking up the wire harness from the floor in the proposed operation 1, the posture was not changed because the percentage of time was deemed lower than that of other activities. For the activity of unsealing the wire harness in the proposed operation 1, no corrective measures were introduced because no problems were observed in the execution of the task. For the activity of routing the wire harness in the proposed operation 1, significant changes were made in this study, which resulted in improvements. Consequently, the changes primarily focused on this activity because it took longer to execute than the other activities. 
Table 7: Activities proposed for operation 1.

\begin{tabular}{cccccc}
\hline \multicolumn{2}{c}{ Operation: tailgate wire harness routing } & & & \\
\hline Time $(\%)$ & Activity & Back & Arms & Legs & Effort \\
\hline 0.69 & 1- Picking up the wire harness from the floor & 4 & 1 & 4 & 1 \\
37.93 & 2 - Unsealing the wire harness & 1 & 1 & 2 & 1 \\
61.38 & 3 -Routing the wire harness & 1 & 2 & 2 & 1 \\
\hline
\end{tabular}

Table 8: Activities proposed for operation 2.

\begin{tabular}{cccccc}
\hline \multicolumn{5}{c}{ Clipping the clamps (line-side assembly) in the tailgate } \\
\hline Time (\%) & Activity & Back & Arms & Legs & Effort \\
\hline 2.18 & 1 - Grabbing the clamps from the tool cabinet & 1 & 1 & 2 & 1 \\
1.75 & 2 - Moving to the tailgate area & 1 & 1 & 7 & 1 \\
96.07 & 3 - Clipping the wire harness & 1 & 3 & 2 & 1 \\
\hline
\end{tabular}

Table 9: Activities proposed for operation 3.

\begin{tabular}{cccccc}
\hline \multicolumn{7}{c}{ Routing the wire harness through the clamps } \\
\hline Time $(\%)$ & Activity & Back & Arms & Legs & Effort \\
\hline 100 & 1 -Threading the wire harness through the clamps & 1 & 3 & 2 & 1 \\
\hline
\end{tabular}

The back posture improved because the operators previously struggled to fit the clamps when routing the wire harness through the hole in the tailgate, thereby bending their back. Upon implementing the new method, the operator managed to perform this activity with a straight back. Postural assessment as a function of time in the software Ergolândia for the proposed operation 1 is presented in Figure 6.

The evaluation showed that no corrective measures were necessary for the back and arm posture. For the legs, corrections were necessary because the operator remains standing up, most of the time, with stretched legs.

New evaluations were performed for the operation of tailgate clamp assembly. For the activities of grabbing the clamps from the tool cabinet, moving to the tailgate area, and mounting the wire harness in the proposed operation 2, no corrective measures were necessary. The result from the evaluation of the back, arms, and legs for the proposed operation 2 from the software Ergolândia is presented in Figure 7.

The results from the postural assessment as a function of time for the activities of operation 2 showed that no corrective measures were needed for the back and arms. In turn, because the arms remained above the shoulder line most of the time, the software Ergolândia determined that corrections were needed as soon as possible. However, the assembly activity cannot be performed using another method for executing the operation. In this case, the most adequate alternative would be to place a platform under the operator to ensure that the arms remained at or below the shoulder line, thereby improving the ergonomics. The legs remain stretched during most of the operating time, thus requiring future corrections. In this case, the company has confirmed the purchase of the ergonomics platform to improve the posture of the operator during the operation under study.

Upon implementing the proposed method, the operator must grab the clamps from the line-side storage and clip them separately to the wire harness. The changes in this operation were not significant because all postural comfort was generated in operation 1; no complaints were identified in operation 2 because this operation is short. Last, the studies of the last operation (routing the wire harness through the clamps) indicated that no corrective measures were necessary for the activity of threading the wire harness through the clamps in the proposed operation 3. Postural assessment as a function of time for the proposed operation 3 from the software Ergolândia is presented in Figure 8. 


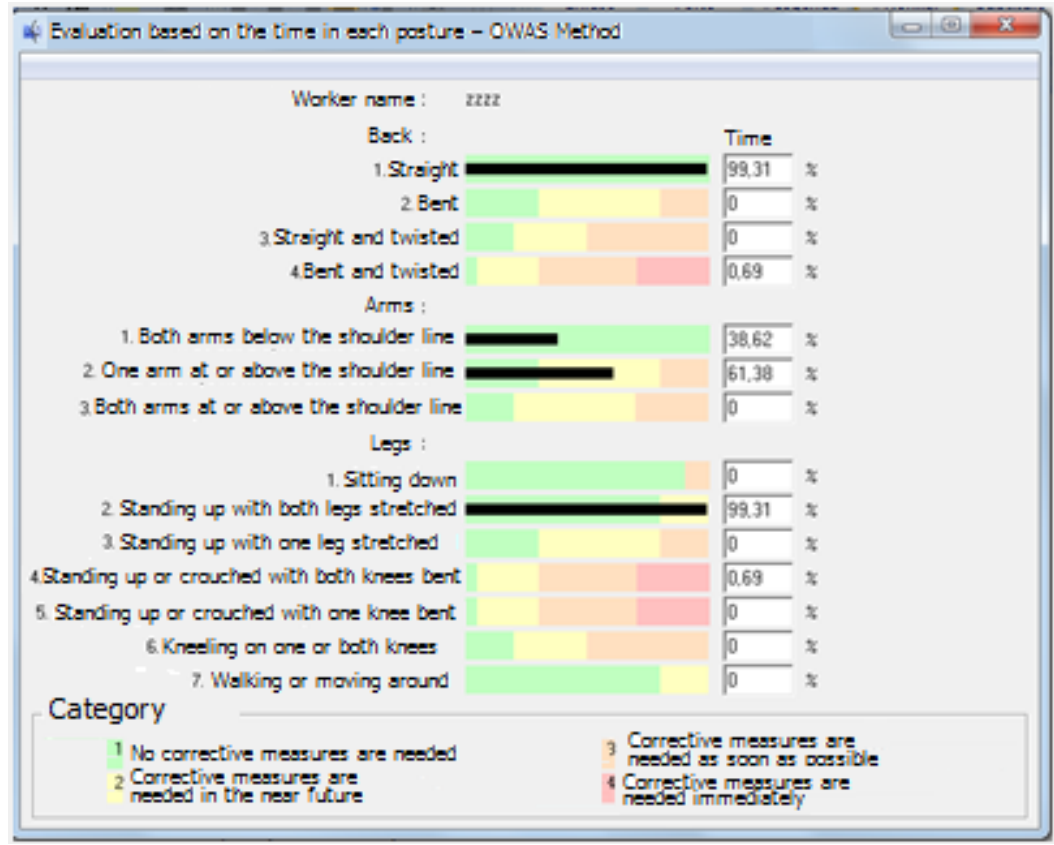

Figure 6: Results from the evaluation of the back, arms, and legs for the proposed operation 1. Source: Adapted from Ergolândia software (2018).

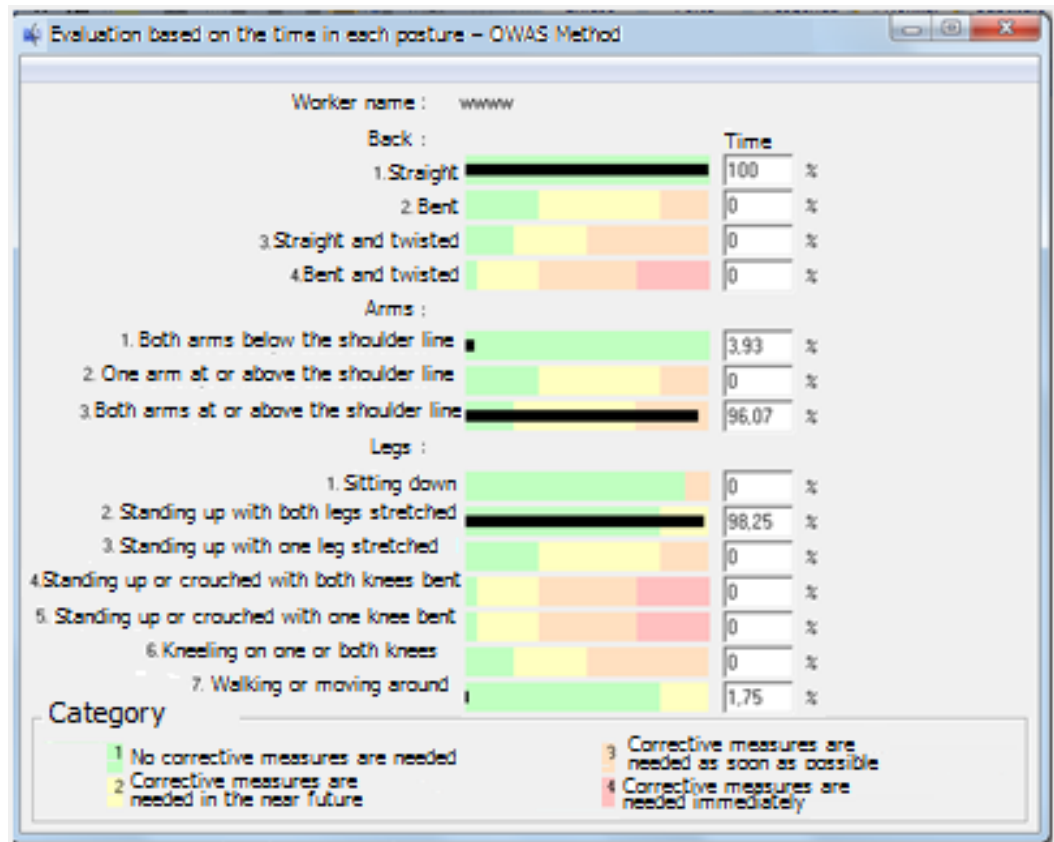

Figure 7: Evaluation of the back, arms, and legs for the proposed operation 2. Source: Adapted from Ergolândia software (2018).

The proposed operation 3 required corrective measures for the back. The arms also needed corrective measures, but this activity is shorter than the other operations. Last, corrective measured were needed for the legs because the operator performs the activity standing up, with both legs stretched. In conclusion, this method can be used for the studied operation because it increases the comfort of the operator whilst executing the operation. When threading the wire harness through the clamps, the operator no longer needs to clip them because this operation is performed at a previous workstation also studied in this project.

After analyzing the results, it can be concluded that the OWAS method, chosen 
to assess working postures, allowed us to identify the activities that present the greatest ergonomic risk. This method, evaluated from a qualitative perspective, presents a high degree of generality and a low degree of sensitivity and can be used for a general assessment, considering that it deals with all body segments and can be adapted to different applications (Weiber, Sales and Saes, 2018). The OWAS becomes a method of low sensitivity because it proposes the analysis of posture without considering the cervical region (neck), wrists and forearms, making it unfeasible when adopting a lying posture (Souza and Rodrigues, 2006).

Given that no tool for evaluating working postures encompasses all the items associated with occupational risks (Pavani and Quelhas, 2006), before using any of them, the task and adopted postures are always analyzed. For the case under study, efforts are not high and the main postures to be evaluated involve analyzing the back, arms and legs, and here the OWAS allows obtaining adequate results.

\section{ANALYSIS OF THE OPERATION TIMES}

\section{Current method}

Time and motion studies Martins et al. (2018) assess the time needed to execute an operation, thus obtaining an immediate result from the work. This type of study was used to analyse the activities performed by the operator at specific times. The time measured in the operation was the observed time; and this time was measured with stopwatch. The study operations and the time needed to perform each task is presented in Table 10.

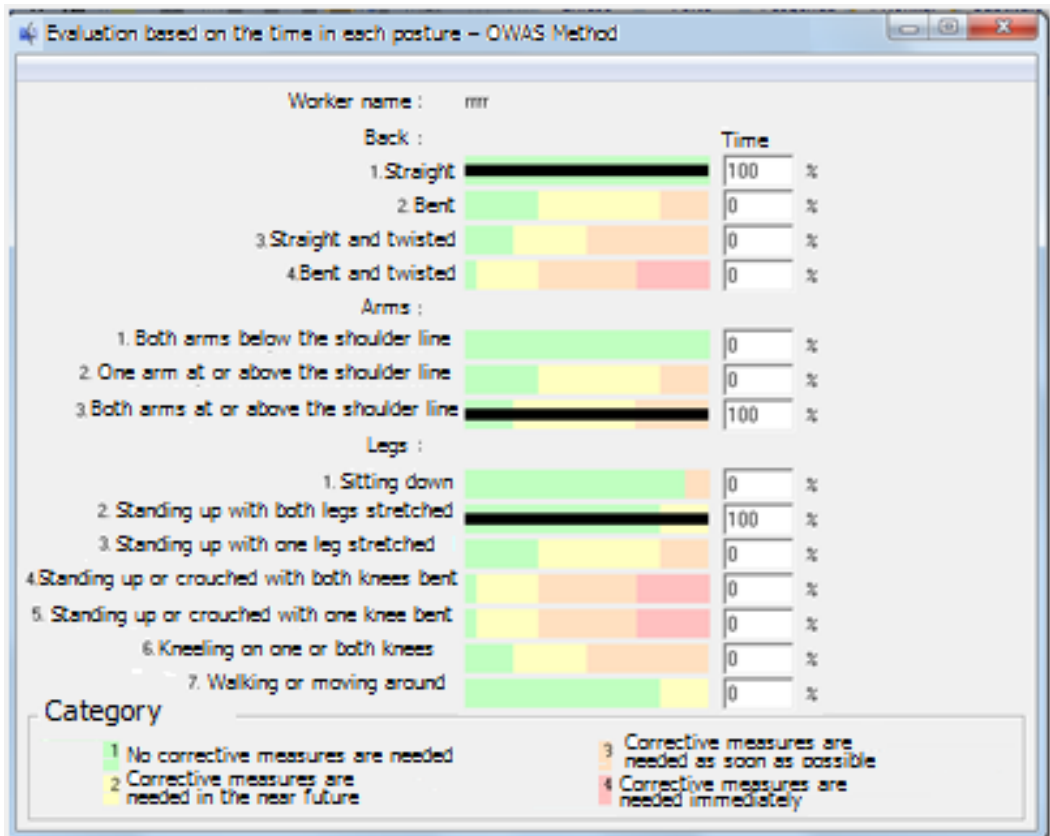

Figure 8: Results from the evaluation of back, arms and legs for the proposed operation 3. Source: Adapted from Ergolândia software (2018).

Table 10: Current operations times.

\begin{tabular}{ccc}
\hline Operation & Activity & Observed time (min) \\
\hline OP 1 & Routing the tailgate wire harness & 1.44 \\
OP 2 & Clipping the clamps attached to the tailgate & 0.44 \\
\hline & Total observed time & 1.88 \\
\hline
\end{tabular}


In the previous situation, in the operation of tailgate wire harness routing, the operator spent a long time with his or her arm raised, compromising his or her occupational health and, consequently, leading to a high rate of complaints at the healthcare centre of the company. Production data show that, in a sixmonth period, six complaints were filed at the healthcare centre.

Because the clamps were attached to the wire harness, the operator struggled to thread the wire harness through the hole in the tailgate, accounting for a high uptime and assembly line stoppages due to operational failures. In the operation of assembling the clamps attached to the tailgate, no major aggravating factors compromising the operator's health were identified.

\section{Proposed method}

Considering the performed analysis and flagging of all problems cited in the previous section, new times were measured for the new work method. For this purpose, line-side measurements of the new operations were performed. The activities were timed as the operator performed the new operations. The operations and the time taken for each task is presented in Table 11.

Table 11 shows a decrease in the routing time. The assembly operation showed no changes despite the addition of the operation of threading the wire harness through the clamps because the observed time of this operation was shorter than the previous and the proposed total time. Furthermore, after the application of the new method, no further complaints were filed in the healthcare centre.

With the proposed method, the operator was able to easily and nimbly perform the operations, shortening the period during which the arm is raised above the shoulder line in the wire harness tailgate routing operation. Changing the work method decreased the physical strain on the operator and, consequently, the rate of complaints filed at the healthcare centre of the company.

The operating time results were evaluated based on the observed total time of the study operations. The data outlined in Table 12 show that applying the proposed method decreases the observed total time by $0.36 \mathrm{~min}$.

According to data from the company under study, the automobile manufacturing time is R \$2.13 (US\$ 0.38). For the vehicle model under study, on average, 120 cars go through the production line per day. The gains are outlined in Table 13 and the productivity calculations are presented in Table 14

For a better visualization of the situation in terms of productivity, a bar chart was constructed to evaluate the significance of the present study to the company, as shown in Figure 9.

As noted in Figure 9, the company productivity increased around $12.6 \%$. Therefore, it can be stated that the results from the time and motion study conducted in this work at the company workstation were satisfactory in terms of productivity.

New work methods that manage to reduce time imply a greater quantity of products obtained, more efficiency and productivity, but what about the human aspect, comfort and safety, in other words, the impact of improvements to the stations from an ergonomic point of view.

In this study, regardless of whether new work methods show the possibility of gaining time and thus increasing work productivity, it was also observed that for some movements, postures are adopted that over time can cause discomfort or the appearance of certain health problems of the workers. The result of applying the OWAS method showed that for operations 2 and 3 specifically the body segments of arms and legs need correction in the near future or as soon as possible.

For this reason, future studies must prove if the measures suggested for the company were taken and also, other methods of posture assessment can be applied to complement the obtained result. The RULA method can be more detailed for some combinations of postures when the arms, forearm and wrist segments are involved. Therefore, studies that combine the OWAS method and the RULA method are suitable to use and the results obtained can be more robust. 
Table 11: Operations times of the proposed method.

\begin{tabular}{ccc}
\hline Operation & Activity & Observed Time (min) \\
\hline OP 1 & Routing the tailgate wire harness & 0.89 \\
OP 2 & Clipping the clamps (line-side assembly) in the tailgate & 0.44 \\
OP 3 & Threading the wire harness through the clamps & 0.19 \\
\hline & Total observed time & 1.52 \\
\hline
\end{tabular}

Table 12: Results from the observed times.

\begin{tabular}{cc}
\hline \multicolumn{2}{c}{ Method times } \\
\hline Previous method total observed time & $1.88 \mathrm{~min}$ \\
Proposed method total observed time & $1.52 \mathrm{~min}$ \\
\hline Total time gain & $\mathbf{0 . 3 6} \mathbf{~ m i n}$ \\
\hline
\end{tabular}

Table 13: Financial gains.

\begin{tabular}{cc}
\hline Description & Gain \\
\hline Financial gain per vehicle & $\mathrm{R} \$ 0.76$ (US\$ 0.38)/vehicle \\
Daily gain (120 vehicles) & $\mathrm{R} \$ 91.20$ (US\$ 16.4) \\
\hline
\end{tabular}

Table 14: Productivity gains.

\begin{tabular}{cc}
\hline \multicolumn{2}{c}{ Increase in productivity } \\
\hline Productivity with the previous method & $53.19 \%$ \\
Productivity with the proposed method & $65.79 \%$ \\
Increase in productivity & $\mathbf{1 2 . 6 0 \%}$ \\
\hline
\end{tabular}

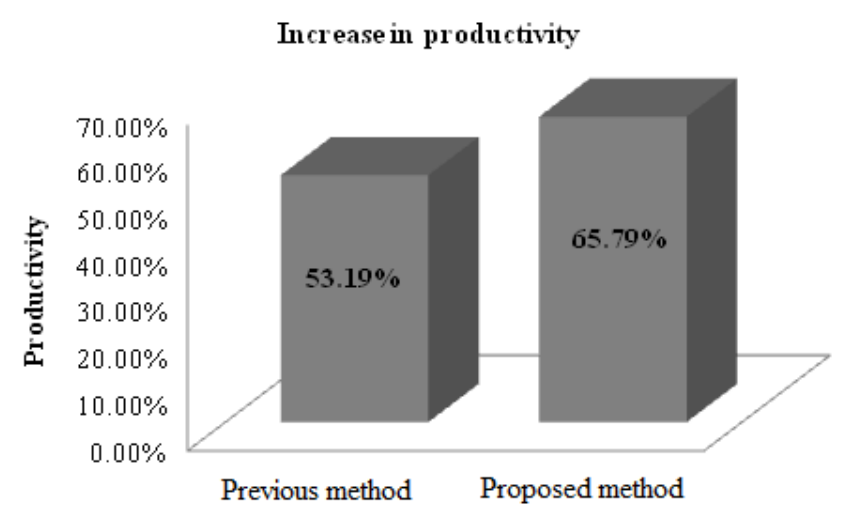

Figure 9: Productivity increasing.

\section{CONCLUSIONS}

The present work applied jointly the concepts of times, movements and ergonomics in the evaluation of jobs in an automobile industry in order to find the best methods to carry out the operations.

It was possible to apply the concepts together because the objective of these areas is the same, finding the best working method, although the means or the way to reach the objective may differ. The area of study of work is concerned with finding the best methods in terms of gains and efficiency and the area of ergonomics incorporates man and his interrelationship with the environment, an important aspect to ensure the comfort, safety and health of the human being to the get the job performed.

In carrying out the study, appropriate tools were used to diagnose the causes of unproductiveness of certain jobs in a production process. The continuous observation of the operating mode was of great importance for obtaining satisfactory results.

New work methods were proposed and evaluated from the perspective of increasing efficiency and productivity without losing the aspects that humanize work. It should also be noted that the analysis of ongoing operations, and even the inclusion of others, can lead to an increase in productivity and also an improvement in ergonomics.

The new methods proposed, in addition to ensuring time savings, were effective from an ergonomic point of view, even with postures that still needed to be corrected. The company assumed as a proposal for future improvement, the installation of a fixed platform in one of the studied stations, so the operator will be at the height of the vehicle, improving ergonomics. With the application of the OWAS method, he showed that the platform will help in cases where the operator has his arms above the shoulder.

It is concluded that this work confirmed how effective the use of adequate methods is in the search to increase the productivity of work posts. Often the methods can have different goals but are not mutually exclusive and their use together can strengthen the results in the improved method. 


\section{REFERENCES}

ABERGO - Associação Brasileira de Ergonomia. Available on <www.abergo.org.br $>$, accessed in: jan 25, 2018.

ALMEIDA, W. A. O. Utilização do método RAPID ENTIRE BODY ASSECEMENT (REBA), associado a diagrama de localização de sintomas e aspectos organizacionais do trabalho, para avaliação de riscos ocupacionais em funcionários da Rádio Rural de Santarém. 26. Monografia (especialização), Faculdade Ávila, Gioânia, 2007.

BARNES, R. M. Estudo de Movimentos e de Tempos: projeto e medida do trabalho, 6st edition. São Paulo: Ed. Edgard Blucher LTDA, 2001.

BRANDL, C.; MERTENS, A.; SCHLICK, C.M. Effect of sampling interval on the reliability of ergonomic analysis using the Ovako working posture analyzing system (OWAS). International Journal of Industrial Ergonomics, 57:68-73, 2017. DOI: 10.1016/j. ergon.2016.11.013

CASTILHO, J. B. S.; BARBIRATO, J. M. R. C.; SALES, C. M. R. Análise postural e ergonômica: estudo das atividades produtivas em uma Cooperativa de Laticínios localizada na cidade de Itaperuna RJ. GEPROS. Gestão da Produção, Operações e Sistemas, Bauru, Ano 11, no 3, p. 39-56, 2016. DOI: 10.15675/gepros.v11i3.1457

ERGOLÂNDIA. Software Ergolândia. Available in <http://www.fbfsistemas.com/ergonomia.html>, accessed on 13 de ap. 2018.

GUIMARÃES, C. P.; NAVEIRO, R. M. Revisão dos métodos de análise ergonômica aplicados ao estudo dos DORT em trabalho de montagem manual. Produto \& Produção, vol. 7, n. 1, p. 63-75, 2004. DOI: 10.22456/1983-8026.1431

JUNIOR, M. M. C. Avaliação Ergonômica: Revisão dos Métodos para Avaliação Postural. Produção Online, 6(3):133-154, 2006. DOI: 10.14488/1676-1901.v6i3.630

LUCAS, P. I. J; SAES, E. V.; TURATI, R. C. Proposta de Aplicação de Conceitos de Engenharia de Métodos e Análise Ergonômica do Trabalho (AET) em Uma Linha de Produção de Água Sanitária: Um Estudo de Caso. Produto \& Produção, 18(1):25-42, 2017. DOI: 10.22456/1983-8026.67115
MARTINS, C. D. A.;SOUZA, A.S.G., FERNANDES, L.A. PENA, H.W.A. Rearranjo do layout produtivo por meio do estudo de tempos e movimentos em uma empresa de grande porte no setor madeireiro. Observatorio de la Economía Latinoamericana, Feb, 2018.

MARTINS, P. G; LAUGENI, F.P. Administração da Produção. $2^{a}$ Edição. Editora Saraiva, 575 p

MAZAHERI, A.; ROSE, L.M. Reaction load exposure from handheld powered tightening tools: A scoping review. International Journal of Industrial Ergonomics, 81:103061, 2021. DOI: 10.1016/j. ergon.2020.103061

NOUROLLAHI-DARABAD, M.; AFSHARI, D. DIANAT, I.; JODAKINIA, L. Long-duration assessment of upper arm posture and motion and their association with perceived symptoms among bakery workers. International Journal of Industrial Ergonomics, 80:103029, 2020. DOI: 10.1016/j. ergon.2020.103029

NR 17. Norma Regulamentadora 17, 1978. Available on <https://www.gov.br/trabalho-e-previdencia/ pt-br/composicao/orgaos-especificos/secretaria-detrabalho/inspecao/seguranca-e-saude-no-trabalho/ ctpp-nrs/norma-regulamentadora-no-17-nr-17>, accessed in: jan 25, 2018.

PAVANI, R. A.; QUELHAS, O. L. G. A avaliação dos riscos ergonômicos como ferramenta gerencial em saúde ocupacional. In:SIMPÓSIO DE ENGENHARIA DE PRODUÇÃO, n. 13, Bauru, 2006. Anais... XIII SIMPEP, Unesp, 2006.

PINTO, A.G.; TERESO, M. J. A.; ABRAHÃO, R.F. Práticas Ergonômicas em um grupo de indústrias da Região Metropolitana de Campinas: natureza gestão e atores envolvidos, Gestão \& Produção, 25(2):398409, 2018. DOI: 10.1590/0104-530X2226-16

SANJOG, J., PATEL, T., KARMAKAR, S. Occupational ergonomics research and applied contextual design implementation for an industrial shop-floor workstation. International Journal of Industrial Ergonomics, 72: 188-198, 2019. DOI: 10.1016/j. ergon.2019.05.009

SOUSA, S.R.O. et al. O estudo de tempos e movimentos na eliminação de desperdícios: Uma aplicação prática na área de limpeza industrial mecanizada. Exacta - EP, 15(3):407-420, 2017. DOI: 10.5585/ExactaEP.v15n3.6892 
SOUZA, J. A. C.; FILHO, M. L. M. Análise ergonômica dos movimentos e posturas dos operadores de checkout em um supermercado localizado na cidade de Cataguases, Minas Gerais. Gestão da Produção, 24(1):123-135, 2017. DOI: 10.1590/0104-530X1376-16

SOUZA, J. P. C.; RODRIGUES, C. L. P. Vantagens e limitações de duas ferramentas de análise e registro postural quanto à identificação de riscos ergonômicos. In: SIMPÓSIO DE ENGENHARIA DE PRODUÇÃO, n. 13, Bauru, 2006. Anais... XIII SIMPEP, Unesp, 2006.

TRZASKOS, J; MICHALOSKI, A. Uma revisão dos métodos de avaliação ergonômica e suas aplicações. CBREPRO, 2015. Available in: < http:// www.aprepro.org.br/conbrepro/2015/down. php?id=1464\&q=1>. Acessed in: mar, 2018.

WEIBER, L. G.; SALLES, L. M. M.; SAES, E. V. Análise comparativa dos métodos ergonômicos para estudo das posturas via aplicação do software Ergolândia: um estudo de caso em uma joalheria. XXXVIII ENCONTRO NACIONAL DE ENGENHARIA DE PRODUCAO, Maceió, Alagoas, Brasil, 16 a 19 de outubro de 2018.

ZANARDIetal.Correlaçõesentrequalidadedevidano trabalho e comprometimento organizacional: Estudo em uma unidade de varejo de vestuário na cidade de Joinville/SC. Produção Online, Florianópolis, 15(2):573-600， 2015. DOI: 10.14488/1676-1901. v15i2.1928 